\title{
Increased fetal hemoglobin levels in patients infected with human immunodeficiency virus (HIV1/2)
}

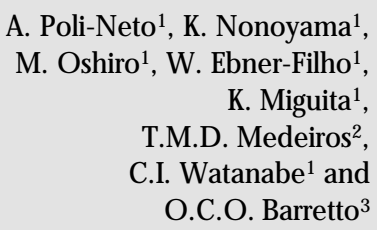

\section{Correspondence \\ O.C.O. Barretto \\ Av. Pedroso de Morais, 70 \\ 05420-000 São Paulo, SP \\ Brasil \\ E-mail: ocdobarr@usp.br}

Presented at the XIII Annual Meeting of the Federação de Sociedades de Biologia Experimental, Caxambu, MG, Brazil, August 26-29, 1998.

Publication supported by FAPESP

Received O ctober 26, 1999

Accepted August 4, 2000

\author{
${ }^{1}$ Seção de Hematologia, Divisão de Patologia, Instituto Adolfo Lutz, \\ São Paulo, SP, Brasil \\ ${ }^{2}$ Departamento de Análises Clínicas e Toxicológicas, Faculdade de Ciências \\ Farmacêuticas, \\ Universidade Federal do Rio Grande do Norte, Natal, RN, Brasil \\ ${ }^{3}$ LIM 23, Instituto de Psiquiatria, Hospital das Clínicas, Faculdade de M edicina, \\ Universidade de São Paulo, São Paulo, SP, Brasil
}

\section{Abstract}

Fetal hemoglobin was measured in HIV1/2 patients under treatment with combined therapy (zidovudine and a protease inhibitor). A total of 143 patients and 103 normal individuals were investigated by the quantitative method of Betke and the semi-quantitative acid elution method of Kleihauer. In the normal person, hemoglobin F makes up less than $1 \%$ and an increase higher than $1.5 \%$ was observed in $21.4 \%$ of HIV patients by the method of Betke and in $24.8 \%$ of HIV-infected patients by the method of Kleihauer. The quantitative biochemical method of Betke showed that the populations were significantly different (two-tailed Mann-Whitney test). The reason for this hemoglobin $\mathrm{F}$ increase might be ascribed to the effect of zidovudine or to direct viral action on gamma chain expression. The finding of a higher F cell frequency indicated by the method of Kleihauer rather suggests that there is an increased $F$ cell clone proliferation rather than an increase in hemoglobin $\mathrm{F}$ level in every cell.

Fetal hemoglobin is composed of two alpha chains coded by a gene located on chromosome 16 and two gamma chains coded by the $A \gamma$ and $G \gamma$ genes located on the chromosome 11 beta gene cluster. Fetal hemoglobin is the major hemoglobin component in the embryonic and fetal mammalian period of life, and at birth it corresponds to about $70 \%$ of all hemoglobins. It decays rapidly throughout the first months and by the first year its concentration stabilizes at $1 \%$. However, there are some hereditary pathological conditions in which increased levels are found, such as thalassemias, hereditary persistence of fetal hemoglobin, and

\section{Key words}

- Human immunodeficiency virus

- HIV1/2

- Hemoglobin

- Fetal hemoglobin

- F cells

- Zidovudine some forms of sickle cell anemia (1). Besides these hereditary disorders, some wellknown acquired diseases exhibit a variable increase in fetal hemoglobin in preleukemic conditions, refractory anemias (2), juvenile myeloid leukemias (1), and neoplasias (3). In the present investigation we studied patients infected with human immunodeficiency virus (HIV) to determine their fetal hemoglobin levels, since some patients were found to present high fetal hemoglobin in our routine hematology work.

A total of $143 \mathrm{HIV} 1 / 2$ class 3 and 4 (CDC of Atlanta) patients who were on treatment with zidovudine (600 mg, daily), sulfo- 
methoxazole, trimetoprim and a protease inhibitor were investigated, as well as 103 normal individuals as controls. Depending upon the presence of other infectious diseases such as tuberculosis, rifampicin, isoniazide, pyrimethamine and pyrazinamide were also given. The populations were from the São Paulo coastal area. HIV1/2 patients were detected with the HIV 1/2 ELISA Abbott test (4) or with the Cambridge Biotech HIV1/2 Western Blot kit $(5,6)$. In both groups, putative heterozygous beta-thalassemia individuals, who exhibited a small increase in fetal hemoglobin, were excluded from this survey when red cells presented microcytosis, hypochromia, no hemolysis at $0.36 \% \mathrm{NaCl}$ and an increase in hemoglobin $\mathrm{A}_{2}$ detected by the elution technique.

Fetal hemoglobin was assessed by two methods: the Betke quantitative biochemical hemoglobin $\mathrm{F}$ alkaline denaturation method (7), and the Kleihauer qualitative cytological method (8) based on the fact that hemoglobin $\mathrm{F}$ does not elute from red cells which are washed with acid solution.

The normal population showed mean hemoglobin $F$ values of $0.98 \pm 0.44 \%$ compared to $1.20 \pm 0.83 \%$ by the method of Betke and HIV-infected patients who presented levels higher than $1.5 \%$ were considered to be the propositi.

In 5000 cells examined by the Kleihauer method, the normal population presented a mean value of $0.5 \pm 0.2 \%$ and $\mathrm{HIV}$-infected patients who exhibited more than $1.5 \%$ of noneluted fetal hemoglobin cells (F cells) were considered to be the propositi.

Table 1 - Hemoglobin $\mathrm{F}(\%)$ and $\mathrm{F}$ cells $(\%)$ in controls and in HIV1/2
patients.
Chi-square between controls and patients with the Betke method:
$\begin{aligned} & \text { 4.17, two-tailed, } \mathrm{P}=0.041 \text {. Chi-square between controls and pa- } \\
& \text { tients with the Kleihauer method: } 4.9 \text {, two-tailed, } \mathrm{P}=0.026 .\end{aligned}$
\begin{tabular}{lll} 
Method & Betke $>1.5 \%$ & Kleihauer $>1.5 \%$ \\
\hline $\begin{array}{l}\text { Controls }(\mathrm{N}=103) \\
\text { HIV patients }(\mathrm{N}=145)\end{array}$ & $\begin{array}{l}10.6 \%(\mathrm{~N}=11) \\
21.4 \%(\mathrm{~N}=31)\end{array} \quad \begin{array}{l}13 \%(\mathrm{~N}=13) \\
24.8 \%(\mathrm{~N}=36)\end{array}$
\end{tabular}

Since the fetal hemoglobin distribution among the controls and patients was nonparametric, the two-tailed Mann-Whitney test was used to analyze the difference in hemoglobin $F$ levels between the controls and the HIV patients and the two populations were found to be significantly different.

A frequency of hemoglobin $\mathrm{F}$ higher than $1.5 \%$ was found to be significantly higher in $\mathrm{HIV}$-infected patients than in controls as determined both by the method of Betke and the method of Kleihauer ( $\mathrm{P}=0.026$, twotailed chi-square test) (Table 1).

The increase in fetal hemoglobin was observed in $21.4 \%$ (Betke) or $24.8 \%$ (Kleihauer) of the patients (Table 1). Fifteen of the patients were positive by both methods, and the remaining ones by one of them. The prevalence of significantly higher hemoglobin $\mathrm{F}$ levels (Betke, chi-square $=4.17, \mathrm{P}=$ 0.041 ) or higher $F$ cell numbers (Kleihauer, chi-square $=4.9, \mathrm{P}=0.026$ ) was observed in $\mathrm{HIV}$-infected patients compared to controls.

A variety of compounds such as erythropoietin (9) and the antineoplastic agents 5azacytidine (10), cytarabine and hydroxyurea (11) have been reported to increase hemoglobin $\mathrm{F}$ concentration in red cells. These compounds have been used for the treatment of sickle cell disease in order to increase hemoglobin $\mathrm{F}$ concentration in red cells, thus preventing the sickle crisis. Charache et al. (12) suggest that this hemoglobin $\mathrm{F}$ increase might be associated with nonrandom hypomethylation of the gammabeta-delta hemoglobin gene complex, and Perrine et al. (13) suggest the occurrence of a block of the biological clock for globin gene switching.

The reason for the hemoglobin increase observed in HIV-infected patients under treatment might be ascribed to the effect of zidovudine or to a direct viral action on the expression of the gamma chain gene. Zidovudine and related dideoxynucleosides inhibit the reverse transcriptase of the virus and induce bone marrow cell suppression 
(14) and erythroblastic changes in human beings.

It is well known that bone marrow suppression leads to normocytic anemia. Megaloblastic anemia is the most frequent finding together with an increase in fetal hemoglobin levels in HIV-infected patients, and in our series all patients, although not presenting anemia, exhibited variable macrocytosis, suggesting a folic acid deficiency induced by a disturbance of folic acid metabolism, by excess folic acid consumption or by poor folic acid intake. However, there are no reports relating megaloblastic anemia to an increase in fetal hemoglobin. Increased fetal hemoglobin is observed after erythroid hyperplasia, as reported by Papayannopoulou et al. (15), who suggested that hemoglobin $F$ may be expressed in erythroid clones derived from BFU-E (burst-forming unit-erythroid) progenitor cells. However, reticulocy- tosis, which could indicate the presence of this erythroid hyperplasia or bone marrow recovery, was not observed in our patients. An increase in fetal hemoglobin might also be induced by action of the virus on gamma chain gene expression, which leads to increased fetal hemoglobin in every red cell, as observed in hereditary persistence of fetal hemoglobin.

Interestingly, the finding of a higher frequency of F cells indicated by the Kleihauer method suggests that, in this case, it is possible that the virus or zidovudine may trigger CFU-E (colony-forming unit-erythroid) differentiation into $\mathrm{F}$ cell clone proliferation. The finding of a higher $F$ cell frequency indicated by the Kleihauer method rather suggests a higher $\mathrm{F}$ cell clone proliferation rather than an increase in fetal hemoglobin in every cell.

\section{References}

1. Weatherall DJ (1995). The thalassemias. In: Beutler E, Lichtman MA, Coller BS \& Kipps TJ (Editors), Williams Hematology. 5th edn. McGraw-Hill, New York, 581-615.

2. Rochant $H$, Dreyfus B, Bouguerra $M \&$ Tant-Hot T (1972). Hypothesis: refractory anemias, preleukemic conditions and fetal erythropoiesis. Blood, 39: 721-726.

3. Ibarra B, Montes J, Becerra C, Pres FJ , Barros-Nuñes $\mathrm{P}$, Aguilar-Luna JC \& ArroyoJ (1991). Hemoglobina fetal em niños con diferentes neoplasias. Sangre, 36: 383-386.

4. Palla P, Moretti A, Pecori F \& Vanacore R (1994). Third-generation HIV-1/HIV-2 ELISA tests. Vox Sanguinis, 67: 240.

5. Tsang VC, Peralta JM \& Simons AR (1983). Enzyme-linked immunoelectrotransfer blot techniques (EITB) for studying the specificities of antigens and antibodies separated by gel electrophoresis. Methods in Enzymology, 92: 377-391.

6. Sarngadharan MG, Popovic M, Bruch L, Schupbach J \& Gallo RC (1984). Antibodies reactive with human T-lymphotropic retroviruses (HTLV-III) in the serum of patients with AIDS. Science, 224: 506-508.
7. Betke K, Marti HR \& Schlicht I (1959). Estimation of small percentage of foetal hemoglobin. Nature, 184: 1877-1878.

8. Kleihauer E, Braun H \& Betke K (1957). Demonstration von fetalem Hämoglobin in den Erythrocyten eines Blutausstrichs. Klinische Wochenschrift, 35: 637-638.

9. Nagel RL, Vichinsky E, Shah M, J ohnson $R$, Spadacino $E$, Fabry $M E$, Mangahas $L$, Abel R \& Stamatoyannopoulos G (1993). $F$ reticulocytes response in sickle cell anemia treated with recombinant human erythropoietin: a double-blind study. Blood, 81: 9-14.

10. DeSimone J, Heller $P$, Hall $L \&$ Zwiers D (1982). 5-Azacytidine stimulates fetal hemoglobin synthesis in anemic baboon. Proceedings of the National Academy of Sciences, USA, 79: 4428-4431.

11. Veith R, Galanello R, Papayannopoulou T \& Stamatoyannopoulos G (1985). Stimulation of F-cell production in patients with sickle-cell anemia treated with cytarabine or hydroxyurea. New England J ournal of Medicine, 313: 1571-1575.

12. Charache A, Dover G, Smith K, Talbot J r CC, Moyer M \& Boyer S (1983). Treat- ment of sickle cell anemia with 5azacytidine results in increased fetal hemoglobin production and is associated with nonrandom hypomethylation of DNA around the gamma-delta-beta globin gene complex. Proceedings of the National Academy of Sciences, USA, 80: 4842-4846.

13. Perrine SP, Faller DV, Swerdlow $P$, Miller BA, Bank A, Sytkowsky AJ, Reczek J, Rudolph AM \& Kan YW (1990). Stopping the biologic clock for hemoglobin gene switching. Annals of the New York Academy of Sciences, 612: 134-140.

14. Yarchoan R, Mitsuya $H$, Myers CE \& Broder S (1989). Clinical pharmacology of 3'-azido-2'-3'-dideoxythymidine (zidovudine) and related compounds. New England J ournal of Medicine, 321: 726-737.

15. Papayannopoulou T, Vichinsky E \& Stamatoyannopoulos $\mathrm{G}$ (1980). Fetal Hb production during acute erythroid expansion. I. Observations in patients with transient erythroblastopenia and post-phlebotomy. British J ournal of Haematology, 44: 535546. 